\title{
Synthesis, Characterization and Biological Evaluation of Novel Acridine Derivatives for Anti-Inflammatory and Analgesic Activities
}

\author{
VARALAKSHMI DEVI KOTHAMUNIREDDY*AND RAJITHA GALLA ${ }^{1}$ \\ Department of Pharmaceutical Chemistry, Sri Krishnadevaraya University College of Pharmaceutical sciences, Sri \\ Krishnadevaraya University, Anantapur, Andhra Pradesh 515003, ${ }^{1}$ Department of Pharmaceutical Sciences, Institute of \\ Pharmaceutical Technology, Sri Padmavati Mahila Visvavidyalayam, Tirupati, Andhra Pradesh 517502, India
}

\section{Kothamunireddy et al.: Evaluation of Novel Acridine Derivatives for Anti-Inflammatory and Analgesic Activities}

Synthesis and investigation of anti-inflammatory and analgesic studies of novel $\mathrm{N}$-(5-substituted phenyl1,3,4-thiadiazol-2-yl) acridin-9-amine derivatives are presented in this article. The title compounds were synthesized by the condensation reaction of 9-chloroacridine and 5-phenyl-1,3,4-thiadiazol-2-amine analogues in presence of $\mathrm{N}$-methyl-2-pyrrolidine and ethyl acetate. All the compounds were screened for their anti-inflammatory and analgesic activities by carrageenan induced rat hind paw edema method and acetic acid induced writhing method respectively. Among the tested compounds, the compound N-(5-(4-chlorophenyl)-1,3,4-thiadiazol-2-yl) acridin-9-amine and N-(5-(4-flourophenyl)-1,3,4-thiadiazol2-yl) acridin-9-amine with chloro and flouro substituents respectively displayed potent activity when compared to the standard drugs. We also investigated the drug likeness score of the synthesized compounds, the drug likeness score was in correlation with the results obtained in biological activity. The semi planar heterocyclic structure of the acridine nucleus may be the reason for its appreciable reactivity with varied biological receptors. In addition, the drug likeness data of synthesized compounds made them promising leads for the future development of anti-inflammatory and analgesic agents.

Key words: Acridine derivatives, anti-inflammatory, analgesic, drug likeness score

At present major health problems faced by mankind are inflammatory and cancer diseases. Various drugs available in the market for the treatment of inflammatory diseases have serious side effects such as gastroduodenal ulcers, dyspepsia, gastritis bleeding etc. and hence cannot be used continuously for long time ${ }^{[1]}$. Acridine nucleus is one of the most versatile and wellknown heterocyclic nucleus, which is seen as common and integral feature of natural products and medicinal agents. Owing to its varied biological activities and industrial applications of acridine derivatives, it has drawn the interest for medicinal chemists. It is present as core structural component in an array of drug categories and is proven as pharmacologically important scaffold. It is well documented that the semi planar heterocyclic structure of the acridine makes it to interact appreciably with different biomolecular targets. Acridine and its derivatives are reported with activities like anti-inflammatory ${ }^{[2,3]}$, anti-cancer ${ }^{[4-7]}$, anti-microbial ${ }^{[8,9]}$, anti-tubercular ${ }^{[10,11]}$, anti-parasitic ${ }^{[12]}$, anti-malarial ${ }^{[13-15]}$, antiviral ${ }^{[16,17]}$, fungicidal $^{[18,19]}$

*Address for correspondence

E-mail: kvaralakshmidevi.kvd@gmail.com

September-October 2021 larvicidal ${ }^{[20-22]}$ and anthelmintic ${ }^{[23]}$ activities. Furthermore, acridines are utilised as dyes, fluorescent dyes for visualization of biomolecules and in laser technologies. A few drugs were also featured with acridine skeleton such as proflavine with antiseptic property, amsacrine with anticancer activity etc. (fig. 1). On the other hand, thiadiazole and their derivatives were studied colossally because of their distinct biological activities. The substituted 1, 3, 4 thiadiazoles are particularly ubiquitous and observed as basic pharmacophore in marketed drugs like acetazolamide, sulfamethizole, cefazolin etc. (fig. 1). In light of the above-mentioned considerations, it is considered as worthwhile to synthesize acridine derivatives fused with thiadiazole ring system.

This is an open access article distributed under the terms of the Creative Commons Attribution-NonCommercial-ShareAlike 3.0 License, which allows others to remix, tweak, and build upon the work non-commercially, as long as the author is credited and the new creations are licensed under the identical terms

Accepted 05 October 2021

Revised 02 July 2021

Received 29 March 2020 Indian J Pharm Sci 2021;83(5):1016-1023 

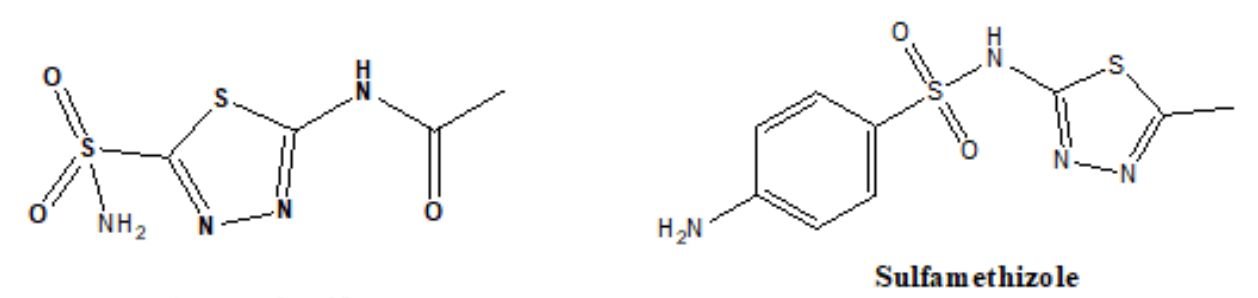

Acetazolamide<smiles>Cc1nnc(CCC2=C(C(=O)O)N3C(=O)C(NC(=O)Cn4cnnn4)C3SC2)s1</smiles>

Cefazoline

Drugs with $1,3,4$ thiadiazole Pharmacophore<smiles>COc1cc(NS(C)(=O)=O)ccc1Nc1c2ccccc2nc2ccccc12</smiles>

Amsacrine<smiles>Nc1ccc2cc3ccc(N)cc3nc2c1</smiles>

Proflavine

Drugs with Acrid ine Pharmacophore

Fig. 1: Drugs with 1,3,4 thiadiazole pharmacophore and acridine pharmacophore

This is coinciding with the previous reports that the addition of aryl rings to the acridine ring system has enhanced the selective binding to the cyclooxygenase- 2 (COX-2) binding site $\left(394 \mathrm{~A}^{3}\right)$ than COX-1 $\left(316 \mathrm{~A}^{3}\right)$ due to enhanced molecular volume of the compounds ${ }^{[24]}$. The present study is an attempt to exploit the antiinflammatory and analgesic activities of the acridine core containing compounds in conjunction with substituted thiadiazole derivatives.

\section{MATERIALS AND METHODS}

All chemicals and solvents were purchased from SD fine and Merck and were used as such without further purification. Clean and sterile laboratory equipment's were used. The melting points of all the reported compounds were determined in open capillaries by using Ana lab melting point apparatus and were uncorrected. The progression of the reaction and homogeneity of the compounds was monitored on Thin Layer Chromatography (TLC) plates using ethyl acetate and n-hexane solvent system. The Infrared (IR) spectrums of the compounds were recorded using
Potassium Bromide (KBr) pellets on a Perkin-Elmer 1760 spectrophotometer. Proton Nuclear Magnetic Resonance ( $\left.{ }^{1} \mathrm{HNMR}\right)$ spectra of the pure compounds were recorded on Bruker Advance $400 \mathrm{MHz}$ spectrophotometer. Chemical shift values (delta- $\delta$ ) were reported in Parts Per Million (ppm). Mass spectral data of the title compounds were recorded on a JEOL JMS-D 300 instrument. Perkin-Elmer 240 analyzer was used for the elemental analysis (Carbon $(\mathrm{C})$, Hydrogen $(\mathrm{H})$, Nitrogen $(\mathrm{N})$ ).

\section{Chemistry:}

General procedure for preparation of 5-substituted phenyl-1,3,4-thiadiazol-2-amine (3a-l): Synthesis of 5-substituted phenyl-1,3,4-thiadiazol-2-amine derivatives was done in accordance with the previously reported procedure ${ }^{[25]}$. During the process of synthesis, various substituted carboxylic acids $(0.1 \mathrm{~mol})$ and thiosemicarbazide $(0.1 \mathrm{~mol})$ in phosphorous oxychloride $(30 \mathrm{ml})$ were refluxed for $30 \mathrm{~min}$ (fig. 2). Then the reaction mixture is cooled, followed by quenching with ice. The separated solid was filtered and suspended in 
www.ijpsonline.com

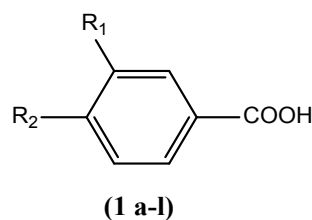

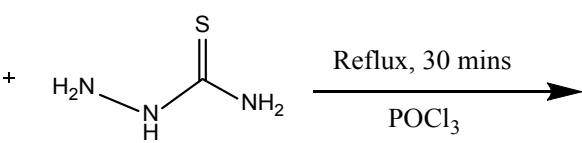

(2)

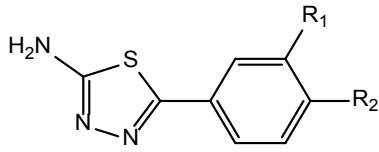

(3 a-1)

Scheme 1

3a $\mathrm{R}_{1}=\mathrm{H}, \mathrm{R}_{2}=\mathrm{H} ; 3 \mathrm{~b} \mathrm{R} \mathrm{R}_{1}=\mathrm{H}, \mathrm{R}_{2}=\mathrm{OCH}_{3} ; 3 \mathrm{c} \mathrm{R} \mathrm{R}_{1}=\mathrm{H}, \mathrm{R}_{2}=\mathrm{NO}_{2} ; 3 \mathrm{~d} \mathrm{R} \mathrm{R}_{1}=\mathrm{NO}_{2}, \mathrm{R}_{2}=\mathrm{H} ; 3 \mathrm{e} \mathrm{R}=\mathrm{H}, \mathrm{R}_{2}=\mathrm{Cl}$; 3f $R_{1}=H, R_{2}=B r ; 3 g R_{1}=H, R_{2}=F ; 3 h R_{1}=B r, R_{2}=B r ; 3 i R_{1}=N_{2}, R_{2}=O_{3} H_{3} ; 3 j R_{1}=O_{3 C H}, R_{2}=O_{3}$; $3 \mathrm{k} \mathrm{R}=\mathrm{H}, \mathrm{R}_{2}=\mathrm{CH}_{3} ; 3 \mathrm{I} \mathrm{R}=\mathrm{CH}_{3}, \mathrm{R}_{2}=\mathrm{H}$;

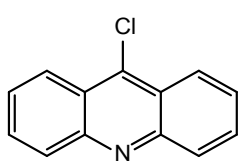

(4)

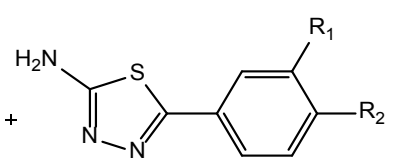

(3 a-l)

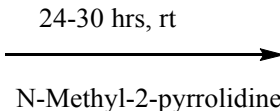

N-Methyl-2-pyrrolidine

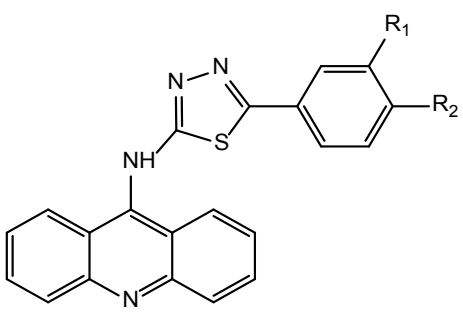

(5 a-l)

Scheme 2

Fig. 2: Preparation of 5-substituted phenyl-1,3,4-thiadiazol-2-amine (scheme 1) and synthesis of N-(5-substituted phenyl-1,3,4thiadiazol-2-yl) acridin-9-amine (scheme 2)

water and basified with aqueous potassium hydroxide. The product is filtered, dried and recrystallized from Dimethyl Formamide (DMF) and ethanol (9:1).

General procedure for the synthesis of N-(5-substituted phenyl-1,3,4-thiadiazol-2yl) acridin-9-amine (5a-l): 9-chloroacridine (1.0 equivalent) and 5-(3,4-substituted phenyl)1,3,4-thiadiazol-2-amine (1.0 equivalent) were added to N-methyl-2-pyrrolidine $(10$ times with reference to weight of 9-chloroacridine). This reaction mixture was stirred at $25-30^{\circ}$ for 24-30 h (fig. 2). The completion of the reaction is monitored by using TLC using Methylene Di Chloride (MDC) and methanol in 8:2 ratio. Then $20 \mathrm{ml}$ of ethyl acetate is added to the mixture, filtered the solid and washed thoroughly with ethyl acetate. Yield is 50-60 \%.

\section{Physical and spectral data of the compounds:}

N-(5-phenyl-1,3,4-thiadiazol-2-yl) acridin-9-amine (5a): Yield: $58 \%$, melting point (MP): 284-286, ${ }^{1} \mathrm{HNMR}$ (dimethyl sulfoxide-d6 (DMSO-d ${ }_{6}$ ) $\delta / \mathrm{ppm}$ : $9.74(\mathrm{~s}, 1 \mathrm{H}, \mathrm{NH}), 8.5-8.2(\mathrm{~m}, 3 \mathrm{H}), 7.9-7.4(\mathrm{~m}, 10 \mathrm{H})$; electrospray ionization mass spectrometry (ESI-MS): $355\left(\mathrm{M}+\mathrm{H}^{+}\right)$, analytically calculated for $\mathrm{C}_{21} \mathrm{H}_{14} \mathrm{~N}_{4} \mathrm{~S}: \mathrm{C}$, 71.16; H, 3.98; N, 15.81; S, 9.05; found $\mathrm{C}, 71.25 ; \mathrm{H}$, $3.89 ; \mathrm{N}, 15.64$.

N-(5-(4-methoxyphenyl)-1,3,4-thiadiazol-2-yl) acridin-9-amine (5b): Yield: 61 \%, MP: 358-360,
${ }^{1} \mathrm{HNMR}\left(\mathrm{DMSO}_{6}\right)$ $\delta / \mathrm{ppm}: 9.78(\mathrm{~s}, 1 \mathrm{H}, \mathrm{NH}), 8.4$ $(\mathrm{m}, 2 \mathrm{H}), 8.0-7.2(\mathrm{~m}, 10 \mathrm{H}), 3.86(\mathrm{~s}, 3 \mathrm{H}$, methoxy $\left.\left(\mathrm{OCH}_{3}\right)\right)$ : ESI-MS: $385\left(\mathrm{M}+\mathrm{H}^{+}\right)$, analytically calculated for $\mathrm{C}_{22} \mathrm{H}_{16} \mathrm{~N}_{4} \mathrm{OS}$ : C, 68.73; H, 4.19; N, 14.57; O, 4.16; $\mathrm{S}, 8.34$, found $\mathrm{C}, 68.43 ; \mathrm{H}, 4.03 ; \mathrm{N}, 14.12$.

N-(5-(4-nitrophenyl)-1,3,4-thiadiazol-2-yl) acridin9-amine (5c): Yield: $56 \%$, MP: 374-376 ${ }^{\circ},{ }^{1} \mathrm{HNMR}$ (DMSO-d $)_{6} \delta /$ ppm: $9.72(\mathrm{~s}, 1 \mathrm{H}, \mathrm{NH}), 8.01(\mathrm{~m}, 2 \mathrm{H})$, 7.62-7.12 $(\mathrm{m}, 10 \mathrm{H})$,: ESI-MS: $400\left(\mathrm{M}+\mathrm{H}^{+}\right)$, analytically calculated for $\mathrm{C}_{21} \mathrm{H}_{13} \mathrm{~N}_{5} \mathrm{O}_{2} \mathrm{~S}: \mathrm{C}, 63.15 ; \mathrm{H}, 3.28 ; \mathrm{N}, 17.53$; $\mathrm{O}, 8.01 ; \mathrm{S}, 8.03$, found $\mathrm{C}, 63.01 ; \mathrm{H}, 3.21 ; \mathrm{N}, 17.40$.

N-(5-(3-nitrophenyl)-1,3,4-thiadiazol-2-yl) acridin9-amine (5d): Yield: $52 \%$, MP: 372-374 ${ }^{\circ},{ }^{1} \mathrm{HNMR}$ (DMSO-d $)$ d/ppm: $9.5(\mathrm{~s}, 1 \mathrm{H}, \mathrm{NH}), 7.87-7.80(\mathrm{~m}, 1 \mathrm{H})$, 7.2-6.5 (m, 11H), ESI-MS: $400\left(\mathrm{M}+\mathrm{H}^{+}\right)$, analytically calculated for $\mathrm{C}_{21} \mathrm{H}_{13} \mathrm{~N}_{5} \mathrm{O}_{2} \mathrm{~S}: \mathrm{C}, 63.15 ; \mathrm{H}, 3.28 ; \mathrm{N}, 17.53$; $\mathrm{O}, 8.01 ; \mathrm{S}, 8.03$, found $\mathrm{C}, 63.05 ; \mathrm{H}, 3.20 ; \mathrm{N}, 17.42$

N-(5-(4-chlorophenyl)-1,3,4-thiadiazol-2-yl) acridin-9-amine (5e): Yield: 60 \%, MP: 358-360, ${ }^{1} \mathrm{HNMR}$ (DMSO-d ${ }_{6}$ ) $/ \mathrm{ppm}: 9.7$ (s, 1H, NH), 8.23-8.22 (m, 2H), 7.75-7.73 (m, 2H), 7.55-7.53 (m, 4H), 7.277.24 (m, 4H); ESI-MS: $389.48\left(\mathrm{M}+\mathrm{H}^{+}\right), 391.50(\mathrm{M}+2)$, analytically calculated for $\mathrm{C}_{12} \mathrm{H}_{13} \mathrm{ClN}_{4} \mathrm{~S}$ : $\mathrm{C}, 64.86 ; \mathrm{H}$, $14.41 ; \mathrm{N}, 14.41$, found $\mathrm{C}, 64.76 ; \mathrm{H}, 3.25 ; \mathrm{N}, 14.12$.

N-(5-(4-bromophenyl)-1,3,4-thiadiazol-2-yl) acridin-9-amine (5f): Yield: 51 \%, MP: 386-388 , ${ }^{1} \mathrm{HNMR}\left(\mathrm{DMSO}_{6}\right.$ ) $\delta / \mathrm{ppm}: 9.72(\mathrm{~s}, 1 \mathrm{H}, \mathrm{NH}), 8.0$ 
(m, 2H), 7.6-7.4 (m, 10H); ESI-MS: $433.8\left(\mathrm{M}+\mathrm{H}^{+}\right)$, $435.90(\mathrm{M}+2)$, analytically calculated for $\mathrm{C}_{12} \mathrm{H}_{13} \mathrm{BrN}_{4} \mathrm{~S}$ : C, 58.2; H, 3.02; Br, 18.44; N, 12.93; S, 7.40 found $\mathrm{C}$, $58.02 ; \mathrm{H}, 3.06 ; \mathrm{N}, 12.82$.

N-(5-(4-flourophenyl)-1,3,4-thiadiazol-2-yl) acridin9-amine (5g): Yield: $53 \%$, MP: 327-328, ${ }^{1} \mathrm{HNMR}$

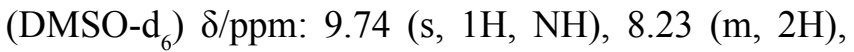
7.7-7.2 (m, 10H); ESI-MS: $372\left(\mathrm{M}-\mathrm{H}^{+}\right)$, analytically calculated for $\mathrm{C}_{21} \mathrm{H}_{13} \mathrm{FN}_{4} \mathrm{~S}$ : C, 58.2; H, 3.02; Br, 18.44; $\mathrm{N}, 12.93 ; \mathrm{S}, 7.40$, found $\mathrm{C}, 58.03 ; \mathrm{H}, 3.01 ; \mathrm{N}, 12.69$.

N-(5-(3,4-dibromophenyl)-1,3,4-thiadiazol-2-yl) acridin-9-amine (5h): Yield: 55 \%, MP: $>380,{ }^{1} \mathrm{HNMR}$

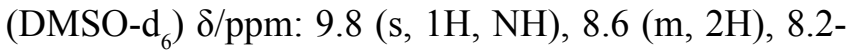
$7.2(\mathrm{t}, 9 \mathrm{H})$, ESI-MS: $513.91\left(\mathrm{M}+\mathrm{H}^{+}\right)$, analytically calculated for $\mathrm{C}_{21} \mathrm{H}_{12} \mathrm{Br}_{2} \mathrm{~N}_{4} \mathrm{~S}: \mathrm{C}, 49.24 ; \mathrm{H}, 2.36 ; \mathrm{Br}$, $31.20 ; \mathrm{N}, 10.94 ; \mathrm{S}, 6.26$, found $\mathrm{C}, 49.13 ; \mathrm{H}, 2.24 ; \mathrm{N}$, 10.89 .

N-(5-(4-methoxy-3-nitrophenyl)-1,3,4-thiadiazol2-yl) acridin-9-amine (5i): Yield: $50 \%$, MP: 356$358^{\circ},{ }^{1} \mathrm{HNMR}$ (DMSO-d $)$ ) $/ \mathrm{ppm}: 9.8(\mathrm{~s}, 1 \mathrm{H}, \mathrm{NH})$, 8.72(m, 2H), 8.4-7.2 (m, 9H), $3.86\left(\mathrm{~s}, 3 \mathrm{H}, \mathrm{OCH}_{3}\right)$ : ESI-MS: $430\left(\mathrm{M}+\mathrm{H}^{+}\right)$, analytically calculated for $\mathrm{C}_{22} \mathrm{H}_{15} \mathrm{~N}_{5} \mathrm{O}_{3} \mathrm{~S}: \mathrm{C}, 61.53 ; \mathrm{H}, 3.52 ; \mathrm{N}, 16.31 ; \mathrm{O}, 11.18 ; \mathrm{S}$, 7.71, found $\mathrm{C}, 61.42 ; \mathrm{H}, 3.45 ; \mathrm{N}, 16.22$.

N-(5-(3,4-dimethoxyphenyl)-1,3,4-thiadiazol-2-yl) acridin-9-amine (5j): Yield: $60 \%$, MP: 352-354,

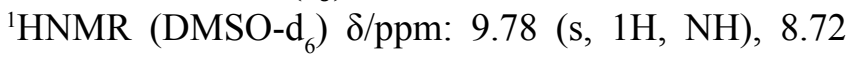
$(\mathrm{m}, 2 \mathrm{H}), 8.6-7.3(\mathrm{~m}, 9 \mathrm{H}), 3.82\left(\mathrm{~s}, 3 \mathrm{H}, \mathrm{OCH}_{3}\right), 3.80$ $\left(\mathrm{s}, 3 \mathrm{H}, \mathrm{OCH}_{3}\right)$ : ESI-MS: $415\left(\mathrm{M}+\mathrm{H}^{+}\right)$, analytically calculated for $\mathrm{C}_{23} \mathrm{H}_{18} \mathrm{~N}_{4} \mathrm{O}_{2} \mathrm{~S}$ : C, 66.65; H, 4.38; N, 13.52; $\mathrm{O}, 7.72 ; \mathrm{S}, 7.74$, found $\mathrm{C}, 66.52 ; \mathrm{H}, 4.23 ; \mathrm{N}, 13.45$.

N-(5-(4-methylphenyl)-1,3,4-thiadiazol-2-yl) acridin-9-amine (5k): Yield: 52 \%, MP: 338-340,

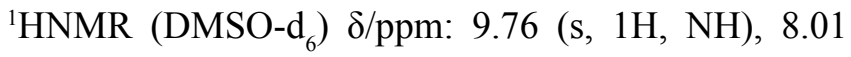
(m, 2H), 7.5-6.9 (m, 10H), 2.34 (s, 3H, Methyl $\left(\mathrm{CH}_{3}\right)$ ): ESI-MS: $369\left(\mathrm{M}+\mathrm{H}^{+}\right)$, analytically calculated for $\mathrm{C}_{22} \mathrm{H}_{16} \mathrm{~N}_{4} \mathrm{~S}$ : C, 71.71; H, 4.38; N, 15.21; S, 8.70, found C, 71.64; H, 4.32; N, 15.11

N-(5-(3-methylphenyl)-1,3,4-thiadiazol-2-yl) acridin-9-amine (5l): Yield: 51 \%, MP: 328-330, ${ }^{1} \mathrm{HNMR} \quad\left(\mathrm{DMSO}_{6}\right) \quad \delta / \mathrm{ppm}: 9.72 \quad(\mathrm{~s}, \quad 1 \mathrm{H}, \mathrm{NH})$, $8.6(\mathrm{~m}, 2 \mathrm{H}), 7.6-6.8(\mathrm{~m}, 10 \mathrm{H}), 2.24\left(\mathrm{~s}, 3 \mathrm{H}, \mathrm{CH}_{3}\right)$ : ESIMS: $369\left(\mathrm{M}+\mathrm{H}^{+}\right)$, analytically calculated for $\mathrm{C}_{22} \mathrm{H}_{16} \mathrm{~N}_{4} \mathrm{~S}$ : C, 71.71; H, 4.38; N, 15.21; S, 8.70, found C, 71.64; H, $4.31 ; \mathrm{N}, 15.12$.

\section{Pharmacological evaluation:}

General: The chemicals used in the pharmacological studies were procured from Merck and Himedia.
Swiss Albino rats of 180-200 g were received from Sri Venkateswara Enterprises, Bangalore. The animal care and maintenance were done in accordance with the ethical guidelines specified by World Health Organization (WHO). All the animals were maintained under regulated conditions of temperature and light. Paw edema of the experimental animals was measured by using Basile 7140 Plethysmometer. Analgesic activity is established by using Eddy's hot plate method. The experimental protocols were approved by the institutional animal ethical committee, with Committee for the Purpose of Control and Supervision of Experiments on Animals (CPCSEA) registration No. SVCOP/IAEC/018/2017-18 and utmost care was taken to ensure that the animals were treated in the most humane and acceptable manner.

Acute toxicity studies: Acute toxicity studies for the title compounds were performed in mice (10 mg/kg to $2000 \mathrm{mg} / \mathrm{kg}$ body weight, orally (p.o)) as per the guidelines of Organisation for Economic Co-operation and Development (OECD) ${ }^{[26]}$. During this study, the control and test compound treated groups were observed for any significant changes in the body weight, food, water intake, any behavioural changes and mortality among the animal groups. The animals were kept starved before $4 \mathrm{~h}$ to the evaluation of the biological activities.

Anti-inflammatory activity: The anti-inflammatory activity of the title compounds was evaluated by carrageenan induced rat paw edema method in Wistar albino rats ${ }^{[27]}$. The experimental animals were divided into six groups. Group 1 is labelled as control group and is given only vehicle that is $0.5 \%$ Carboxymethyl Cellulose (CMC) solution, while groups 2 to 4 were administered synthesized compounds (200 mg/kg body weight) as homogenous suspension in aqueous solution of sodium CMC $(0.5 \% \mathrm{w} / \mathrm{v})$ by p.o route. Groups 5 and 6 were assigned as the standard groups and received diclofenac and celecoxib. The rats were injected with test compounds and standard drug $1 \mathrm{~h}$ prior to the administration of carrageenan suspension ( $0.05 \mathrm{ml}$ of $1 \%$ suspension) in the sub plantar region of rat hind paw to induce inflammation. A mark was made at the lateral malleolus and the foot was immersed to the same extent into the arm of plethysmograph. The volume of the injected paw is measured immediately after the carrageenan injection by water displacement method in a digital plethysmograph. The paw edema volume is again measured after 30,60, 120 and $180 \mathrm{~min}$. Average edema volumes for the test and 
standard treated groups were compared statistically with those of control group and expressed as the percentage edema inhibition which was calculated using the formula

Percentage inhibition $=100\left(1-\mathrm{V}_{\mathrm{t}} / \mathrm{V}_{\mathrm{c}}\right)$

Where $\mathrm{V}_{\mathrm{c}}$ is the volume of the edema in the control group and $\mathrm{V}_{t}$ the volume of the edema in the treated group. Statistical significance of the results was tested by Analysis of Variance (ANOVA) and Dunnett's t- test.

Analgesic activity by writhing method: The analgesic activity of the title compounds is evaluated by a chemical method namely acetic acid induced writhing ${ }^{[28,29]}$. The basic concept behind this screening process is that the injected chemical produces pain reaction which is characterized by a writhing response such as constriction of abdomen, trunking of the trunk and extension of the hind limbs. The Swiss albino mice of 20-30 g were chosen and divided into groups, each consisting of five animals. The animals were administered with the test compounds and standard drug aspirin $100 \mathrm{mg} / \mathrm{kg}$ p.o for a group as positive control and $\mathrm{CMC}$ as negative control for a group. Then after $1 \mathrm{~h}, 10 \mathrm{ml} / \mathrm{kg}$ dose of $0.6 \%$ acetic acid was injected intraperitoneally. The mice were observed for the total number of writhes for 15 min starting 5 min after the acetic acid injection and the total number of writhes was recorded. The mean value of writhes for each group was calculated and compared statistically with the vehicle treated control group. The mean value, SEM was calculated for all groups and percentage inhibition of the number of writhes is calculated by using the formula, Percentage $(\%)$ analgesic activity $=100\left(1-\mathrm{W}_{\mathrm{t}}-\mathrm{W}_{\mathrm{c}}\right)$, where $\mathrm{W}_{\mathrm{t}}$ is the average number of writhes observed in test group and $\mathrm{W}_{\mathrm{c}}$ is the average number of writhes observed in control group. Statistical significance of the results was tested by ANOVA and Dunnett's t- test.

\section{RESULTS AND DISCUSSION}

The synthesis of the title compounds N-(5substituted phenyl-1,3,4-thiadiazol-2-yl) acridin9-amine derivatives (5a-1) was carried out as per the scheme outlined in the fig. 2. The intermediate, 5-(3,4-substitutedphenyl)-1,3,4-thiadiazol-2-amine (3a-1) was prepared by the condensation of the various substituted aromatic carboxylic acids (1a-1) with thiosemicarbazide. Then the above obtained thiadiazole derivatives (3a-1) upon reacts with the 9-chloroacridine (4) in presence of N-methyl-2-pyrrolidine (fig. 2) afforded the title compounds.
The chemical structures of the synthesized compounds were in full agreement with the spectral data obtained. In the ${ }^{1} \mathrm{HNMR}$ spectra the signals related to the protons of the title compounds were verified and the structures were established. The ${ }^{1} \mathrm{HNMR}$ spectra of the title compounds ( $5 \mathrm{a}-1)$ showed a singlet at $\delta 9.0$ to 9.6 group due to $\mathrm{NH}$ proton and aromatic protons were observed as multiplet at $\delta 6.5$ to 8.1. In mass spectra of all the synthesized compounds (5a-1), the molecular ion peaks are all in accordance with their molecular weights. Detailed spectral data is given in experimental protocols. The elemental analysis data of all the compounds were in good agreement with the theoretical values.

Biological evaluation was described below. Acute toxicity studies showed that the compounds were safe up to $2000 \mathrm{mg} / \mathrm{kg}$ p.o dose and no mortality or gross behavioural changes were observed in the animals used.

Anti-inflammatory activity of the compounds is shown here. Carrageenan induced rat hind paw method is used to measure the inhibitory potencies of the compounds (5a-1) against the inflammatory process. From the results obtained (Table 1 and fig. 3), the compounds (5a-1) exhibited profound anti-inflammatory activity when compared with the standard drug, diclofenac. Among them the compounds 5e $(69.4 \%)$ with chloro group as substituent exhibited remarkable antiinflammatory activity, followed by the compounds $5 \mathrm{f}$ $(67.7 \%)$ with bromo group, $5 \mathrm{~g}(63.5 \%)$ with flouro group and $5 b(62.5 \%)$ with methoxy group showed significant and comparable activity with the standard drug diclofenac $(71.6 \%)$. The semi planar heterocyclic structure of the acridine nucleus makes it to react appreciably with varied biological receptors. Most of the COX-2 inhibitors with proven activity possess substituents like $\mathrm{Cl}, \mathrm{F}, \mathrm{NO}_{2}$ etc. along with diaryl ring system.

The title compounds are evaluated for analgesic activity by using acetic acid induced writhing assay at $100 \mathrm{mg} / \mathrm{kg}$ p.o (Table 1 and fig. 4). Among all the compounds, compound $5 \mathrm{e}(71.2 \%)$ and $5 \mathrm{~g}$ $(68.2 \%)$ with chloro and flouro groups respectively as substituents was found to possess equipotent analgesic activity when compared with the standard drug aspirin (68.2\%). Compounds 5 b exhibited significant analgesic activity.

Drug likeness score of the synthesized compounds were predicted using molsoft online server tool (Table 2). Good drug likeness scores of 0.65 and 0.55 were obtained for $5 \mathrm{e}$ and $5 \mathrm{~g}$ compounds with chloro and flouro substituents, respectively. This result 
TABLE 1: ANTI-INFLAMMATORY AND ANALGESIC ACTIVITIES OF TITLE COMPOUNDS

\begin{tabular}{lccccc}
\hline S. No & Compound & $\mathrm{R}_{1}$ & $\mathrm{R}_{2}$ & $\begin{array}{c}\text { Anti-inflammatory activity } \\
\text { \% inhibition }\end{array}$ & $\begin{array}{c}\text { Analgesic activity } \\
\text { \% inhibition }\end{array}$ \\
\hline 1 & $5 \mathrm{a}$ & $\mathrm{H}$ & $\mathrm{H}$ & $54.2^{* * *}$ & $50.9^{* * *}$ \\
2 & $5 \mathrm{~b}$ & $\mathrm{H}$ & $\mathrm{OCH}_{5}$ & $62.5^{* * *}$ & $66.5^{* * *}$ \\
3 & $5 \mathrm{c}$ & $\mathrm{H}$ & $\mathrm{NO}_{2}$ & $46.4^{* * *}$ & $47.1^{* * *}$ \\
4 & $5 \mathrm{~d}$ & $\mathrm{NO}_{2}$ & $\mathrm{H}$ & $45.2^{* * *}$ & $46.1^{* * *}$ \\
5 & $5 \mathrm{C}$ & $\mathrm{H}$ & $\mathrm{Cl}$ & $69.4^{* * *}$ & $71.2^{* * *}$ \\
6 & $5 \mathrm{H}$ & $\mathrm{H}$ & $\mathrm{Br}$ & $67.7^{* * *}$ & $62.5^{* * *}$ \\
7 & $5 \mathrm{~g}$ & $\mathrm{H}$ & $\mathrm{F}$ & $65.5^{* * *}$ & $68.2^{* * *}$ \\
8 & $5 \mathrm{~h}$ & $\mathrm{Br}$ & $\mathrm{Br}^{*}$ & $47.4^{* * *}$ & $50.0^{* * *}$ \\
9 & $5 \mathrm{i}$ & $\mathrm{NO}_{2}$ & $\mathrm{OCH}_{5}$ & $44.0^{* * *}$ & $59.4^{* * *}$ \\
10 & $5 \mathrm{j}$ & $\mathrm{OCH}_{5}$ & $\mathrm{OCH}_{5}$ & $59.5^{* * *}$ & $61.5^{* * *}$ \\
11 & $5 \mathrm{~K}$ & $\mathrm{H}$ & $\mathrm{CH}_{5}$ & $59.0^{* * *}$ & $55.7^{* * *}$ \\
12 & $5 \mathrm{Cl}$ & $\mathrm{CH}_{5}$ & $\mathrm{H}$ & $48.4^{* * *}$ & $51.9^{* * *}$ \\
13 & Standard drug & Diclofenac & & $71.6^{* * *}$ & $68.2^{* * *}$ \\
\hline
\end{tabular}

Significance levels ${ }^{*} \mathrm{p}<0.05,{ }^{* *} \mathrm{p}<0.01$ and ${ }^{* * *} \mathrm{p}<0.001$ by Dunnet test. At $100 \mathrm{mg} / \mathrm{kg}$ (p.o) edema volume was measured $5 \mathrm{~h}$ after carrageenan and activity is presented as \% inhibition of inflammation. NT-Not tested

Significance levels ${ }^{*} p<0.05,{ }^{* *} p<0.01$ and ${ }^{* * *} p<0.001$ by Dunnet test when compared with acetic acid treated control group

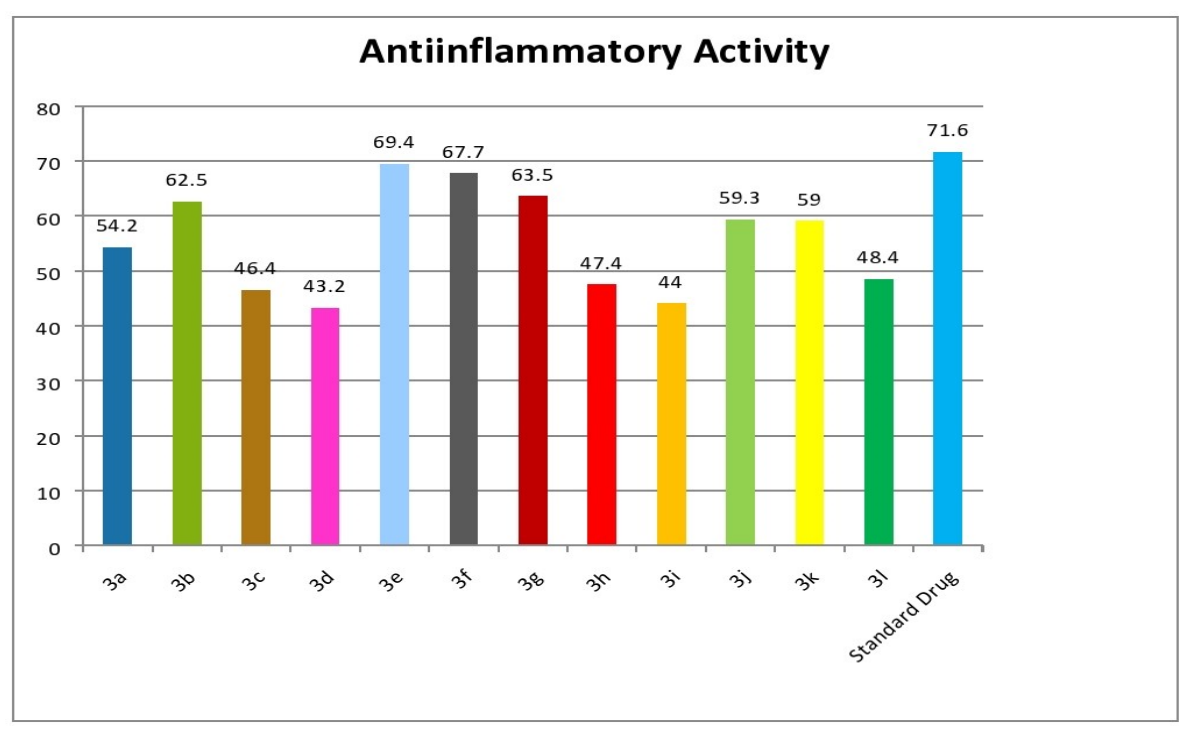

Fig. 3: Graphical representation of anti-inflammatory activity of title compounds

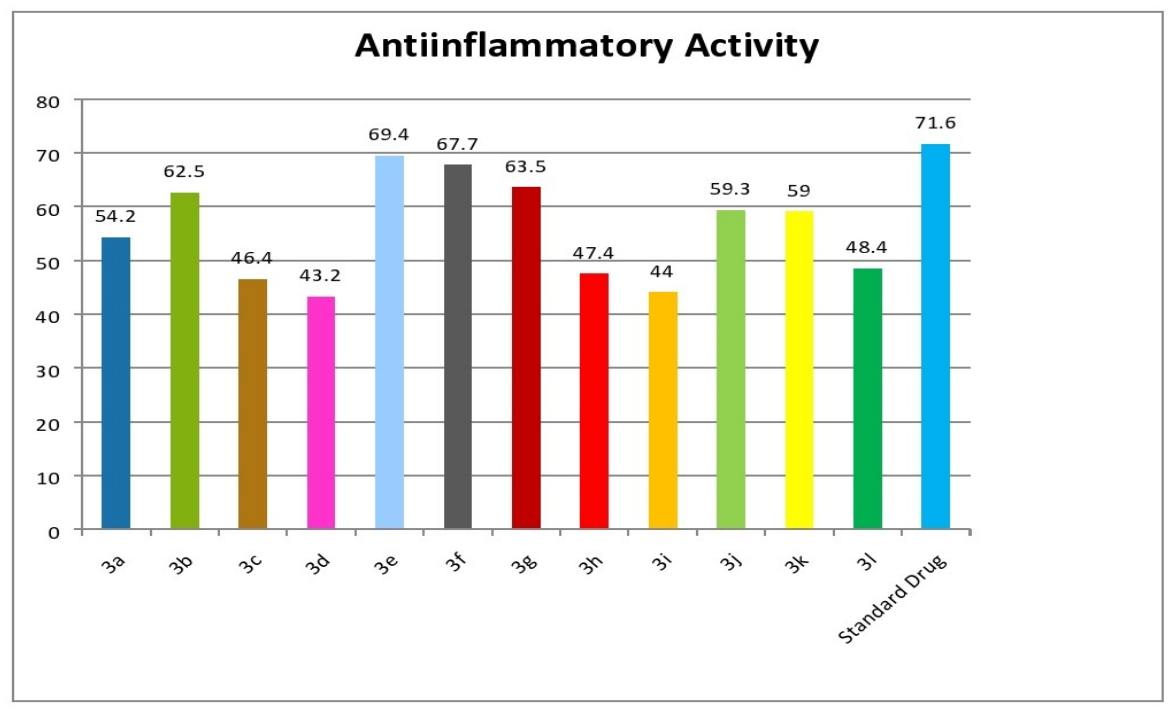

Fig. 4: Graphical representation of analgesic activity of title compounds 
www.ijpsonline.com

TABLE 2: DRUG LIKENESS SCORE OF THE TITLE COMPOUNDS

\begin{tabular}{lcc}
\hline S. No & Compound & Drug likeness score \\
\hline 1 & $5 \mathrm{a}$ & 0.06 \\
2 & $5 \mathrm{~b}$ & 0.47 \\
3 & $5 \mathrm{c}$ & -0.51 \\
4 & $5 \mathrm{~d}$ & -0.54 \\
5 & $5 \mathrm{e}$ & 0.65 \\
6 & $5 \mathrm{f}$ & 0.52 \\
7 & $5 \mathrm{~g}$ & 0.55 \\
8 & $5 \mathrm{~h}$ & -0.08 \\
9 & $5 \mathrm{i}$ & -0.62 \\
10 & $5 \mathrm{k}$ & 0.55 \\
11 & $5 \mathrm{l}$ & 0.19 \\
12 & $5 \mathrm{~m}$ & 0.19 \\
\hline
\end{tabular}

is adding support to the biological activities observed for these compounds.

In the present study, some $\mathrm{N}-(5$-substituted phenyl1,3,4-thiadiazol-2-yl) acridin-9-amine derivatives (5a-1) were synthesized and were screened for antiinflammatory and analgesic activities. Among the tested compounds, the compounds $5 \mathrm{e}$ and $5 \mathrm{~g}$ displayed potent activity when compared to the standard drugs. Thus, the study emphasizes the importance of acridine pharmacophore as anti-inflammatory and analgesic agents.

\section{Acknowledgements:}

We are thankful to Council of Scientific \& Industrial Research-Indian Institute of Chemical Technology (CSIR-IICT), Hyderabad and to Principal, Raghavendra Institute of Pharmaceutical Education and Research (RIPER), Anantapur for providing the spectral data.

\section{Conflicts of interest:}

The authors declared no conflict of interest.

\section{REFERENCES}

1. Sondhi SM, Singh J, Rani R, Gupta PP, Agrawal SK, Saxena AK. Synthesis, anti-inflammatory and anticancer activity evaluation of some novel acridine derivatives. Eur J Med Chem 2010;45(2):555-63.

2. Chen YL, Lu CM, Chen IL, Tsao LT, Wang JP. Synthesis and antiinflammatory evaluation of 9-anilinoacridine and 9-phenoxyacridine derivatives. J Med Chem 2002;45(21):468994.

3. Sondhi SM, Johar M, Singhal N, Dastidar SG, Shukla R, Raghubir R. Synthesis and anticancer, antiinflammatory and analgesic activity evaluation of some sulfa drug and acridine derivatives. Monatsh Chem 2000;131(5):511-20.

4. Chen J, Li D, Li W, Yin J, Zhang Y, Yuan Z, et al. Design, synthesis and anticancer evaluation of acridine hydroxamic acid derivatives as dual Topo and HDAC inhibitors. Bioorg Med Chem 2018;26(14):3958-66.
5. Guo QL, Su HF, Wang N, Liao SR, Lu YT, Ou TM, et al. Synthesis and evaluation of 7-substituted-5, 6-dihydrobenzo [c] acridine derivatives as new c-KIT promoter G-quadruplex binding ligands. Eur J Med Chem 2017;130:458-71.

6. Zhang W, Zhang B, Yang T, Wang N, Gao C, Tan C, et al. Synthesis and antiproliferative activity of 9-benzylamino-6chloro-2-methoxy-acridine derivatives as potent DNA-binding ligands and topoisomerase II inhibitors. Eur J Med Chem 2016;116:59-70.

7. Barros FW, Silva TG, da Rocha Pitta MG, Bezerra DP, CostaLotufo LV, de Moraes MO, et al. Synthesis and cytotoxic activity of new acridine-thiazolidine derivatives. Bioorg Med Chem 2012;20(11):3533-9.

8. Gupta SK, Baboo P. Antimicrobial activity of synthesized novel n10-alkyl substituted acridine-9-one derivatives. Int J Pharm Chem Anal 2014;1(1):39-46.

9. Kudryavtseva TN, Lamanov AY, Klimova LG, Nazarov GV. Synthesis and antimicrobial activity of acridine carboxylic acid derivatives containing a piperazine moiety. Russian Chemical Bulletin. 2017 Jan;66(1):123-8.

10. Ilango $\mathrm{K}$, Arunkumar S. Synthesis, antimicrobial and antitubercular activities of some novel trihydroxy benzamido azetidin-2-one derivatives. Trop J Pharm Res 2011;10(2):219-29.

11. Aly EI, Abadi AH. Synthesis and antitubercular activity of 6-chloro (unsubstituted)-2-methoxy-9-substituted acridine derivatives. Arch Pharm Res 2004;27(7):713-9.

12. Carole DG, Michel DM, Julien C, Florence D, Anna N, Severine J, et al. Synthesis and antileishmanial activities of 4,5-di-substituted acridines as compared to their 4-monosubstituted homologues. Bioorg Med Chem 2005;13(19) 5560-8.

13. Valdes AF. Acridine and acridinones: old and new structures with antimalarial activity. Open Med Chem J 2011;5:11-20.

14. Opsenica I, Burnett JC, Gussio R, Opsenica DM, Todorovic $\mathrm{N}$, Lanteri CA, et al. A chemotype that inhibits three unrelated pathogenic targets: the botulinum neurotoxin serotype a light chain, P. Falciparum malaria and the Ebola Filovirus. J Med Chem 2011;54(5):1157-69.

15. Auparakkitanon S, Noonpakdee W, Ralph RK, Denny WA, Wilairat P. Antimalarial 9-anilinoacridine compounds directed at hematin. Antimicrob Agents Chemother 2003;47(12):3708-12.

16. Lyakhov SA, Lyakhova EA, Panchenko NN, Litvinova LA, Andronati SA. Synthesis and antiviral activity of new bisacridinylhydrazides of aryloxyacetic acids. Pharma Chem J 2001;35(12):653-6.

17. Tonelli M, Vettoretti G, Tasso B, Novelli F, Boido V, Sparatore $\mathrm{F}$, et al. Acridine derivatives as anti-BVDV agents. Antiviral Res 2011;91(2):133-41.

18. Viscia SM, Brodie DC. The in vitro antifungal activity of a series of acridine salts. J Am Pharm Assoc 1954;43(1):52-4.

19. Sompalle R, Roopan SM, Priya DD, Suthindhiran K, Sarkar G, Ranjith M, et al. Microwave-Assisted Synthesis of Positional Isomeric Dihydro-triazolo-pyrimido-acridines and Biological studies. ChemistrySelect 2020;5(10):3085-90.

20. Bharathi A, Roopan SM, Rahuman AA, Rajakumar G. (E)2-Benzylidene-7-chloro-9-phenyl-3, 4-dihydroacridin-1 (2 $\mathrm{H})$-ones: synthesis and larvicidal activity. Res Chem Intermed 2015;41(4):2453-64.

21. Bharathi A, Roopan SM, Rahuman AA, Rajakumar G. Solvatochromic behaviour and larvicidal activity of acridine3-carboxylates. J Photochem Photobiol B 2014;140:359-64.

22. Roopan SM, Bharathi A, Al-Dhabi NA, Arasu MV, Madhumitha G. Synthesis and insecticidal activity of acridone derivatives 
to Aedes aegypti and Culex quinquefasciatus larvae and nontarget aquatic species. Sci Rep 2017;7(1):1-6.

23. Gollapalli NR. Green synthesis, characterization, and antihelminthic activity of newer quinoline derivatives containing acridine Moiety. Asian J Pharm Clin Res 2017;10(9):377-80.

24. Bhardwaj A, Kaur J, Sharma SK, Huang Z, Wuest F, Knaus EE. Hybrid fluorescent conjugates of COX-2 inhibitors: Search for a COX-2 isozyme imaging cancer biomarker. Bioorg Med Chem Lett 2013;23(1):163-8.

25. Keerthi Kumar CT, Keshavayya J, Rajesh TN, Peethambar SK, Shoukat Ali AR. Synthesis, characterization, and biological activity of 5-phenyl-1,3, 4-thiadiazole-2-amine incorporated azo dye derivatives. Org Chem Int 2013.
26. OECD. Acute oral toxicity-acute toxic class method, test guideline No.425. OECD Guidelines for the testing of chemicals; 2001.

27. Winter CA, Risley EA, Nuss GW. Carrageenin-induced edema in hind paw of the rat as an assay for antiinflammatory drugs. Proc Soc Exp Biol Med 1962;111(3):544-7.

28. Galla R, Prasad K, Bharathi K. Synthesis and biological evaluation of 5-amino pyrazolones. Asian $\mathrm{J}$ Chem 2011;23(2):684-6.

29. Hafez HN, Hegab MI, Ahmed-Farag IS, El-Gazzar AB. A facile regioselective synthesis of novel spiro-thioxanthene and spiro-xanthene-9', 2-[1, 3, 4] thiadiazole derivatives as potential analgesic and anti-inflammatory agents. Bioorg Med Chem Lett 2008;18(16):4538-43. 